(2) Training grade posts had preferential access to M.R.C.Psych. courses.

(3) Study time was given on a pro-rata basis, which might mean that additional time was spent outside 'working' hours in travelling and attendance on courses.

(4) The Department, e.g. a University Department running the course might exclude nontraining grade applicants.

(5) Many of the non-training grade posts, particularly that of Clinical Assistant, had limited clinical experience, in that their working time was spent in circumscribed areas of clinical work. This inevitably hindered their appreciation of any educational course available to them.

The increasing number of Registrar rotating schemes sometimes makes it difficult to allow a parttime training post to be integrated, as the holder may need to stay twice as long in any module to gain adequate experience. It might be recommended that recognized training posts for part-timers should be maintained outside the rotation in all Areas, but allowing equal access to all modules.

Some of the anomalies raised could be dealt with by taking part-time training posts out of the hands of Regional and Area Authorities, to be funded centrally.

The 'pairing' of training posts-seen as a cheap economic solution-will prevent the single applicant from obtaining a post, and thus bar her from access to further training.

The principle of access to educational facilities being available to all grades-whether training or non-training must be accepted. The Clinical Assistant grade is particularly disadvantaged in that the holder not only may have to pay for further training but must often use her 'free' time for attendance at courses. The latter she may choose to do, but the financial disincentive should be removed, either by waiving fees, or providing one or two paid sessions for attendance at courses (a precedent already exists in Section 63 payments to general practitioners attending educational courses).

With few exceptions there seemed among the respondents much enthusiasm and determination to enable the part-time woman to have as full and adequate training and educational opportunity as her full-time peer. Many comments suggested that the anomalies and inadequacies lay more often at administrative level, where procrastination occurred, partly because of funding problems. There did, however, seem to be evidence in some Areas of resistance to the whole concept of the part-time woman doctor, and more particularly to her achieving further seniority if her qualifications increased.

It would seem that it is at this administrative level that the College needs to press for improvement to ensure a continuing entry of women into psychiatry, and to allow full utilization of their increasing skills within the specialty thereafter.

\section{References}

Savage, R. \& Wirson, A. (1977) Foumal of the Royal College of General Practitioners, 27, 363.

Brack, D. (1974) News and Notes. British Fournal of Psychiatry. October: $\mathrm{p}$ 10.

Ashurst, P. (1975) News and Notes. British Journal of Psychiatry. April: p 9.

Broox, C. P. (1976) Report to the Working Party on Women in Psychiatry.

HM(69)6. Department of Health and Social Security, I969.

Need Part-Time be Second Rate? British Medical Joumal (1977), ii, 210

\title{
PAPERS FOR THE ANNUAL MEETING, $197^{8}$
}

The Programmes and Meetings Committee invites members of the College to submit papers on miscellaneous topics for presentation at the Annual Meeting, which is to be held on 4,5 and 6 July 1978. Depending on the number offered, the Committee is prepared to make arrangements for parallel sessions to enable as many papers as possible to be read. I would be grateful to hear from members who have papers which they would like to present. The closing date for the receipt of summaries is 28 February 1978 .

E. G. LuGAs

Honorary Secretary

Programmes and Meetings Committee 